students for the sort of citizenship demanded by the United States' new place in the world ? Dr. Reinhold Niebuhr tries to make this new place clear. It is one in which three new conditions prevail : America has become the acknowledged leader of the free world; is faced with a powerful and resolute rival ; and must apparently live with a 'nuclear stalemate'. In this precarious position, technology is no doubt important ; but Dr. Niebuhr thinks that an understanding of Russian imperialism and the curious American 'antiimperialist imperialism' is equally so. It is necessary to have representatives abroad who speak the languages and understand the cultures of those among whom they are living; and though there is no study that will enable one to forecast the future, the study that does most to equip one for understanding the larger problems of the day is history.

Hans Morgenthau puts his emphasis in a different place. Agreeing that history is important, he thinks it could best be taught and understood not as a string of events but as the exemplification of principle, and above all, the principle that nations seek power. A thorough grasp of this principle, as exemplified historically, would throw more light on the present scene than any study of the events or personalities of the day.

The fifth group of articles examines the social matrix within which education in the United States operates. Prof. Margaret Mead looks into the reasons for the separation between the world of the scientist and that of his intended audience, the general population. In this way she points to the mechanism that may be responsible for the widening of the gap between the intellectual and society at large. Prof. David Riesman directs attention to the medium in which the academic himself grows and moves-lest educators seek the sources of their difficulties only outside the sphere of their own organizational setting.

Most of the papers have been edited by Prof. Brand Blanshard, who has also contributed an introduetion to them. For background, this special issue of Daedalus also contains a reprint of A. N. Whitehead's famous essay on "The Aims of Education", which was first written some forty years ago. For those concerned with education, this essay may serve the purpose of periodic re-dedication as well as any other source.

\title{
PUBLIC LIBRARIES IN ENGLAND AND WALES
}

$\mathrm{T}$ HE report of the Committee appointed by the Minister of Education in September 1957 to consider the structure of the public library service in England and Wales* reviews briefly the development of the public library service and the changing views of its functions, particularly the changes in formal structure since the Kenyon Committee reported in 1927. Turning then to the public library service to-day, it suggests that three main questions arise : how a really adequate service throughout the country can best be provided; the standards for judging the efficiency of a library service; and the requisite conditions which will enable a local authority to provide an efficient service. Chapters on the future structure of public library administration, library co-operation, staff and premises, the position in Wales, library charges and library legislation follow. The principal recommendations are that the Minister of Education, assisted by two advisory bodies for England and Wales, respectively, should exercise a general responsibility for the public library service, with powers to enforce the discharge of its statutory duty by any library authority he considers to be in default. Every public library authority should have a statutory duty to provide an efficient library service, and the minimum annual expenditure on the purchase of books expected from a non-county borough or urban district council as an independent library authority should be $£ 5,000$ or $2 s$. per head of the population. All library authorities should be given powers to appoint library committees diroctly responsible to the councils.

The existing regional committees should be given statutory recognition and required, under schemes approved by the Minister, to provide a satisfactory system of library co-operation within their regions and to work in conjunction with the National Central

* Ministry of Education. The structure of the Public Library Service in England and Wales: Report of the Committee appointed by the Ministry of Education in September 1957. Pp. iv +57 . (Cmnd 660.) (London : H.M. Stationery Office, 1959.) 3s. 6d. net.
Library. The local authorities should contribute substantially to the cost of the National Central Library, with greater representation on its governing body and in its administration. An adequate series of regional catalogues and the catalogue at the National Central Library should be completed as a rnatter of urgency and with a non-recurrent Treasury grant. Extra-distriet charges should be abolished for readers using libraries outside their own areas. Salary scales for the staff of public libraries should be commensurate with their qualifications and responsibilities and so applied as to make career prospects attractive. To meet the need for considerable improvement in public library premises and for many new library buildings a higher priority should be given to capital expenditure for this purpose. No charge should be made to borrowers of books or other material except for notification that the book or material is available or for retention beyond a prescribed period, and legislative provision should be made authorizing the levying of these charges by library authorities.

A new Public Libraries Act should be passed to give effect, so far as is necessary, to these recommendations and giving all library authorities specific powers to combine or co-operate with each other, and with education and other authorities, to provide lectures and cultural activities, to provide and lend such material as gramophone records and films and to acquire land compulsorily for library purposes under the Act. It is also recommended that the position of local authorities responsible for museum and art galleries should be considered, since it may be necessary to legislate separately for librarios, museums and art galleries in future. A minority report by $\mathrm{Mr}$. J. Bulman and $\mathrm{Mr}$. S. J. Skillen enters reservations as to the type of local authority which should become or remain library authorities and dissents from the suggestion as to a minimum expenditure on books. 